\title{
IMPROVING QUALITY OF ISLAMIC EDUCATION THROUGH COMMUNITY BASED EDUCATION: PRINCIPAL ENGAGEMENT
}

\author{
Arbi \\ Universitas Islam Negeri (UIN) Sultan Syarif Kasim Riau \\ Jl. H. R. Soebrantas No. 155 Km. 15 Simpang Baru Panam Pekanbaru, Indonesia, 28292 \\ Email: arbiyasin@uin-suska.ac.id
}

Received: 02, 2018. Accepted: 06, 2018. Published: 06, 2018.

\begin{abstract}
The emergence of a community-based education paradigm is triggered by a large flow of modernization and democratization. Education should be decentralized. Its implementation in schools should be collaborative and the principal has a big role in this program. Therefore, this study aims to examine the involvement or participation of the principal in improving the quality of community-based PAI (Pendidikan Agama Islam/Islamic Education) in junior high school. The data were collected through indepth interview, observation, literature studies and documentation instruments. This study shows that the principal's concern on religious affairs and the improvement of the quality of PAI learning is relatively high. This can be seen from his programs in conducting: recitation on Islamic and national holidays, Duba learning program, tahfid (one day one verse), daily book of yaumi, tajwid learning, tahsin for teachers, qurban payment collection, motivation program for improving teachers' skills, existing curriculum development, and teaching competence based on social piety program.
\end{abstract}

Keywords: Islamic education, Quality, Head Master, Community-based.

\begin{abstract}
ABSTRAK
Kemunculan paradigma pendidikan berbasis masyarakat dipicu oleh arus besar modernisasi dan demokratisasi. Pendidikan harus dikelola secara desentralisasi, pelaksanaannya di sekolah barus kolaboratif, Kepala Sekolah punya andil besar dalam bal ini. Oleh karenanya, penelitian ini bertujuan untuk mengkaji keterlibatan atau peran serta Kepala Sekolah dalam peningkatan mutu Pendidikan Agama Islam (PAI) berbasis masyarakat di SMP Negeri I Bukitbatu. Data dijaring lewat wawancara mendalam, pengamatan terlibat dan studi kepustakaan serta instrumen dokumentasi. Kajian ini menunjukkean bahwa kepedulian kepala sekolah pada persoalan-persoalan keagamaan dan peningkatan mutu pembelajaran PAI relatif cukup tinggi, terutama kelihatan dari kegiatan-kegiatannya mengadakan program pengajian pada hari-hari besar Islam dan nasional, pengajian Duba, program tabfidz satu hari satu ayat, mengadakan buku amalan yaumi dan buku setoran ayat, program belajar tajwid atau tabsin bagi para guru, program cicilan hewan qurban dan sangat memotivasi para guru untuk memiliki keterampilan, mengembangkan kurikulum yang ada, serta meningkatkan kompetensi mengajar berbasis kesalehan sosial.
\end{abstract}

Kata Kunci : Pendidikan Islam, Mutu, Kepala Sekolah, Berbasis Komunitas.

\section{INTRODUCTION}

Implementation of Law Number of 22 Year 1999 regarding Regional Autonomy and Government Regulation Number 25 Year 2000 on Division of Authority Between Central and Regional Government brings a paradigm shift in education management approach (Casson \& Obidzinski, 2002). The pattern of centralized education management shifts to decentralization. Central government responsibilities shift to local government (Faguet, 2004). Similarly, in decision making in the field of education, there is a shift to local government or school (Stromquist, 2007). Education plans and programs that rely on funds from the central government should shift to efforts to mobilize local resources (Rondinelli, 1981). Thus, the successfulness in education, whether public education or religious education, is not only the 
responsibility of the central government but also the provincial, district, school, and community or education stakeholders (Aksit, 2007). This is relevant to the concept of development and development of community-based participation (community-based development participation) and school-based management. However, the most haunting factor and one of the most fundamental and crucial issues in Indonesian education are the low quality of education at every level and unit of education, especially primary and secondary education, especially in the field of PAI in public schools (Mazrui, 1992).

The existence of parents, community leaders, alumnies, teachers, principals, and school committee members has the potential to improve the quality of Islamic education in junior high school (Khong \& Ng, 2005). The facts show that there is a gap between reality (das sein) and what should be (das sollen), where the performance and process of the implementation of community-based education are still relatively low. It is coupled with a pattern of centralized educational management that has a major impact on the weakening of the aspects of input aspects of Islamic Education (Kim, 2013). The involvement or participation of key stakeholders is still suboptimal in contributing to the quality improvement of Islamic Education, while the output of Islamic Education, including indicators of attitude and practice of religion students always showed a negative and apprehensive, morality students increasingly affected by modern life (E Johnson-Agbakwu, Helm, Killawi, \& I Padela, 2013).

Recognizing the above facts, the study on improving the quality of PAI is very important for minimizing, reducing, and avoiding the morals and bad behaviour of the students. There are many reports for solving this problem, for example as reported by (Bell, Connerley, \& Cocchiara, 2009). However, most of the reports did not discuss about the condition in Indonesia as a developing countries with the most populous Muslim in the world. Because of that, the main questions in this study are (1) how the performance and the process of implementation of community-based Islamic education, and (2) How the involvement or participation of principal in improving the quality of Islamic Education based community in junior high school. Therefore, this study aims to examine the involvement or participation of the principal in improving the quality of PAI community-based in junior high school. As a model of the school as the main target, SMPN I Bukitbatu Bengklis Riau was selected.

\section{METHOD}

Data were collected through in-depth interviews, observations, literature studies, and documentation instruments. As a model, SMPN (Sekolah Menengah Pertama Negeri/Junior High School) Bukitbatu, Riau, Indonesia, was selected. The question is arisen for an interview: the principal's concern on religious affairs and the quality improvement of PAI learning. It can be seen from his programs conducting recitation on Islamic and national holidays, Duba (one of prays in Islam) learning program, tabfid₹ (memorizing al-Qur'an verses) one day one verse, books of yaumi (one kind of lesson in Islam) and verse books, tajwid (learning to read al-Qur'an) learning or tabsin (learning to read al-Qur'an aloud) for teachers, qurban (one of compulsory sunnab to sacrifice of a livestock animal during 'Ied al-Adha) and highly motivating teachers to have skills, develop existing curriculum, and improve the competence of teaching based on social piety.

\section{RESULTS AND DISCUSSION}

It has been understood that the implementation of community-based education is utilized to improve the quality of PAI in SMPN I Bukitbatu Bengklis Riau. This study was to examine and evaluate the quality improvement of PAI aspects, which includes: the teacher's training and competence, the procurement books and learning tools, the facilities and infrastructure's improvement, and the school management quality improvement in the religious aspect. The school principal's role has undergone significant changes since the last edition of the 
international encyclopedia was published (Crow \& Peterson, 2010). The importance of the knowledge society, the globalization of society, and the increasing demographic diversity of schools have called for new, or at least changed, roles for school principals. Clearly, the specific nature of these changes varies with national and regional contexts; but internationally too, the roles of principals are changing (Brinthaupt \& Lipka, 2012; Cheung, 2000; Crow \& Peterson, 2010; Dimmock \& Walker, 2000).

\section{PAI Teachers Training and Competence}

PAI teachers are one of the main factors in improving the quality of PAI in SMPN I Bukitbatu Bengkalis Riau that needed serious attention. The noble personalities of the teachers play a very important role in developing good values in students (Noh, Ludin, \& Suhid, 2013). Similarly, teachers' abilities to plan manage and implement the teaching and learning process is a key factor in achieving the goal of teaching. Skills in creativity, designing and implementing teaching and learning are inextricably linked with their duties and responsibilities as educators. Moreover, SMPN I Bukitbatu Bengkalis Riau has an Islamic teacher who is professional and effective as his key to progress and success in Islamic Education learning process in the school. Even further, educational figure has done research on the performance and role of this teacher (Whittington, 1996). The results shows that teacher's role and performances are very significant for every successful learning process in school.

Therefore, efforts and efforts must be made by the school to improve the Islamic Education's teacher competences. According to Ornstein (1991), effective teachers are those with high competency in knowledge and skills. Hence teachers entail to continuously improving knowledge and skills to enhance and explore their teaching practices to be a competent teacher. Competency is the possession of adequate skills and understanding to complete certain task and work satisfactorily (Rafee, 2014). Teaching requires competencies and standards that contain the principles and guidelines in order to be successful as a teacher. One of which is to include them in training and improving PAI teacher's competence, both at the level of Bengkalis and Riau Province. It goes without saying that teacher training boost teacher skill, competence and knowledge to the next level. It can be expected that they will perform better and better in delivering PAI material.

In September 2009, the school gave an opportunity to PAI teachers to attend the certification training conducted by the Faculty of Tarbiyah and Teacher-Training UIN Suska Riau in Pekanbaru and in 2014, two teachers of PAI in school just got the opportunity to attend certification training at Riau Province level also held by Faculty of Tarbiyah and TeacherTraining UIN (Universitas Islam Negeri/State Islamic University Sultan Syarif Kasim Riau as LPTK (Lembaga Pendidikan Tenaga Kependidikan/Educational Institutions for Educational Staff) Section 213. It seems that the opportunities were available for them. Even though their chance to participate in the training is not ample enough.

Thus, all teachers of Islamic Education have attended PLPG (Pendidikan dan Latihan Profesi Guru/the Teacher Professional Training), have got the certificate of educator and passed the certification of teacher in position, and recognized as a professional teacher in the field of Islamic Education (PAI). It is expected that certification for training of PAI teachers can improve teacher's competence and teacher be able to contribute to the quality improvement of PAI in the school (Ahmad, 1998). Quality teaching is in line with the competence that the teachers performed. Their performance and competence were proven in their passing of teacher certification.

Similarly, the Principal of SMPN I Bukitbatu Bengkalis Riau through in-depth interview expressed as follows: Teacher's Certification Training is a prestigious training, and can improve the welfare of teachers who follow. It also can improve the performance and competence of teachers in teaching. It is therefore, a golden opportunity for teachers of Islamic Education who 
have attended the certification training, as not all teachers are selected and have the opportunity to attend certification training that can create a reliable and professional teachers. The teachers of Islamic Education here have undergone tremendous changes to the certification training. Many new breakthroughs related to the quality improvement of their community-based PAI have occurred. The sacrificial animal slaughtering program, bringing the congregational prayers at the Al-Mukarromah Mosque of Pertamina, one day one verse and inviting the ustadz that weighs from the outside to give recitations every day of Islam and national day. This is clear evidence as a result of their teacher certification training that they have struggled with.

\section{Procurement of Books and Learning Tools of PAI}

According to one Islamic teacher in SMPN I Bukitbatu Bengklis Riau, who stated about the importance of book as the main media in learning process that can be expressed as follows: Books as a media in PAI is very urgent and plays an important role in improving learning quality. There are basic instruction books or handles that are required and there are books as a development and complement. The problem is sometimes the book came not sufficient, sometimes quite a lot and sometimes undone because the centralistic location of the school. In 2017, the seventh grade textbook of PAI came too much more than the target number of student, while for the eighth grade textbook of PAI has not came at all and interrupted the learning process, especially in terms of assigning tasks to the students. To solve this problem, there are many solutions. Likewise, school has taken one through the Principal and the School

Committee and it is not resolved. School also has to try to find a way out by itself. If not yet addressed last choice is contacted the parents or asked the children to photocopy a small part of the book that is essential to the study (Creswell, 2012; Lewis \& Tsuchida, 1999).

\section{Improvement of Facilities and Infrastructure of PAI}

Facilities and infrastructure of PAI owned by SMPN I Bukitbatu Bengkalis Riau can be quite adequate. In 2016, Bengkalis District Education Office provided assistance for renovation of study room, damaged seats, rehabilitate school mushalla (small mosque) and received assistance of the Al-Qur'an as much as 150 pieces. These supporting materials will boost religious learning activities for students in their school.

Disclosed by the Principal of SMPN I Bukitbatu Bengkalis Riau through interview data collection techniques that "Facilities and infrastructure that exist today thank God is relatively adequate and in accordance with the state of the number of personnel existing students. Especially, the study room was renovated, damaged seats have been repaired, musholla has been under construction, we received 150 al-Qur'an from Bengkalis District and we bought the book of Islamic Education from the BOS funds center of 2017 as much as 450 pieces, to be used as a mandatory one for student Islamic Education."

Based on the results of interview above, it can be understood that in SMPN I Bukitbatu Bengkalis Riau facilities and infrastructure is quite adequate. This becomes one of the supporting factors to the PAI learning process, which is conducive. In line with the above explanation also disclosed by one of the teachers of PAI at SMPN I Bukitbatu Bengklis Riau as follows: School facilities and infrastructure are supporting the teachers' work here. We can compare teachers equipped with adequate facilities and infrastructure with teachers who are not equipped with adequate facilities and infrastructure. Teachers equipped with adequate facilities and infrastructure would show a better learning performance than the teacher who would not do so. Currently, the facilities and infrastructure that are needed by teachers of Islamic Education are a laptop or notebook.

When interviewing teachers of PAI at SMPN I Bukitbatu Bengklis Riau, they reinforced and revealed about the needs of facilities and infrastructure for Islamic Education that support the upcoming learning process. In the coming years, they expect schools to be iconic, pre- 
eminent and religious. So the facilities and infrastructure needed will be much different from the existing facilities and infrastructure such as a complete laboratory, adequate library, canteen, and cooperative syar'i, as well as beautifully arranged teacher room worthy of worship. And, it is very important to be cleaned (Fielding, 2009). Places are the most visible aspects for all stakeholders in the school and their condition should be maintained in the best condition.

\section{Improving the Quality of School Management in the Field of Religion}

Schools implementing Community-Based Quality Improvement Management should have clear and adequate management input (Fullan \& Watson, 2000). The principal has a big role to play in improving the community-based management quality at the school. So far, the programs have been undertaken to improve community-based management in schools is only linked to the improvement of the Principal's leadership through the Principal Management Training conducted by the Bengkalis District Education Office in 2016.in other words the program had not touched many aspects relating to school as a whole.

When interviewing the Principal of SMPN I Bukitbatu Bengklis Riau, He/she explained that in January 2016, the Principal of SMPN I Bukitbatu Bengklis Riau and others were invited by the Head of Bengkalis District Education Office to attend the Principal Management Training. From the training, they were able to know and understand that Principal Management Training that was useful in: (1) enhancing professional skills in carrying out administrative and supervisory tasks, (2) improving the capacity of teaching, student, staffing, budgeting, with the community, and (3) improving the school principals and principals' perspective in facing the school dynamics of internal and external factors affecting school life.

The Principal Management Training that has been held, it was proven to be capable enough to improve the competence of Principal of SMPN I Bukitbatu Bengklis Riau in enhancing the quality of community-based school management, if the program were implemented properly. It is just that it needs to link with untouched programs and areas of religion. Through subsequent interview, Principal of SMPN I Bukitbatu Bengkalis Riau explained and revealed about the definition of school. The school is a public school but it concerns with religious issues or PAI. In the quality management programs in the field of religious education, the principal and teachers have to apply the system with regard to teachers as teachers and with activities of students. It will create experiences for the learning process. Among others, there are important points: (1) Every teacher of SMPN I Bukitbatu Bengkalis Riau who is Muslim learn tajwid or tabsin with wife of Basyrul Syam (one of the Islamic preacher in Indonesia) at his house in Kampung Jawa of Pakning River on every Friday afternoon. (2) The teachers have an installment program of Rp. 200,000 per month. By 2016, we have been able to slaughter a cattle sacrifice of three animals, and by the year 2017, a slight economic downturn was difficult to be two cows only. The slaughter of sacrificial animals and the sacrificial committee involved the local community. The meat was distributed to underprivileged students, only five people got a coupon per class. SMPN I Bukitbatu Bengkalis Riau has 18 classes, so much meat that can be shared to the community ( $5 \times 18=90$ people) outside the committee and teachers in this school. (3) They have to prepare zakat fitrah, infak care boxes of Bosnia, Palestine, Aceh, basket of orphans and hard people, floods, sick people, disasters, people died, and others. In 2017, they still keep infak (like charity) for orphans and low-income people as much as Rp. 12.000.000,-. (4) The program also must force teachers to teach in Islamic and national holidays. Although many packs must be provided for the teachers whom we have invited to give a lecture or lecture here. (5) They have to prepare Duba learning program, tabfiz one day one verse program, Qur'anic recitation art, marbabaan, al-barzanji, kompang, rebana, calligraphy, Malay Islamic poetry, Malay arabic, Syahril Qur'an, speeches and pesantren kilat on the month of Ramadan at Masjid Al-Mukarromah Pertamina. 


\section{Principal Involvement or Participation for Increasing the Values of Islamic Teaching, Attitudes and the Application of Students' Religion}

The involvement or participation of Principal of SMPN I Bukitbatu Bengkalis Riau in improving the value of PAI, attitude and practice of students' religion is determined by three indicators. The indicators are (1) Principal succeeds in increasing PAI value, attitude and practice of student's religion; (2) The principal often motivates PAI teachers and students to improve the achievement of PAI values, attitudes and practices of the students 'religion; (3) the principal often evaluates the PAI score improvement program, attitude and practice of the students' religion.

The involvement or participation of Principal of SMPN I Bukitbatu Bengkalis Riau in the success of increasing the value of PAI, attitude and practice of students' religion can be classified high enough. It can be seen from the average value of PAI, attitudes and practice of religious students is quite good. Thus, it can be concluded on the first indicator that principal has played an optimal role. The success of Principal of SMPN I Bukitbatu Bengkalis Riau happened due to many factors that influence in increasing the value of PAI, attitude and practice of student religion.

Principal of SMPN I Bukitbatu Bengkalis Riau explained carefully during interview. The problem of PAI student is not lies in the acquisition of merely the values listed in the report book. However, problem was found from the attitudes or behaviors displayed by students every day. The practice of the students' daily religion must be reflected and determined by the PAI teacher in giving good value

The second indicator is the Principal of SMPN I Bukitbatu Bengkalis Riau often motivates PAI teachers and students to improve the value of PAI, attitude and practice of students' religion. These are classified as the high category. Because almost every occasion, the principal gives direction to students in order to improve their learning achievement in PAI, attitude, and morals as well as religious practice. This problem is confirmed by principal itself during the questioning that researchers must be followed the order. For example, every ceremony on Monday, principal often gives directions to students to be diligent and serious in learning PAI, improving attitude, maintaining politeness with everyone, and keep their religious deeds everywhere. This must be applied at both home and school. As for the teachers, especially for PAI teachers, in monthly meeting that held by the principal, he/she always demands to evaluate the development of student achievement, attitude, behavior and religion's practice. Then, teacher should act like parent during the learning process (as students' father or mother) in the class. In addition, teachers must understand student's problem that can be disturbed and changed the school good reputation.

The third indicator, the main point is the Principal of SMPN I Bukitbatu Bengkalis Riau must often evaluate the program that mean to be increase the value of PAI, attitude and practice of the students' religion. This must be categorized high. This has been verified by the plan made by the Principal of SMPN I Bukitbatu Bengkalis Riau, either every semester or every year. This is an evident from the excavation and filtering data through intensive interviews with the Principal. The idea is principal together with teachers of PAI in SMPN I Bukitbatu Bengkalis Riau usually hold meeting in every new academic year to evaluate the development of PAI values, attitudes, behavior, and practice of students' religion. This is very important to earn good PAI value along with good attitude or behavior pattern from students. This is also supported by students' high participation in religion practice. Indeed, that factor becomes standard. Furthermore, the Principal together with the teachers of PAI determine strategy to improve the achievement or value of PAI, attitude and religion's practice of the students by organizing additional community-based programs likewise books, involving parents and school 
committee, and students who are having trouble with their religious attitudes and practices, they can be optimally fostered and addressed as soon as possible.

Based on the above three indicators, the involvement or participation of the Principal in increasing the value or achievement of PAI, the attitude and religion's practice of students are the main factors (Galindo \& Sheldon, 2012), in which it has been stated above, looks to get high or optimal. However, in the realistic condition, it still needs further researches, more thorough and more depth, because many important aspects and indicators have not been touched on in this scientific research, due to limitation of time and money.

\section{Principal Involvement or Participation in Improving PAI Teacher Competence.}

The involvement or participation of Principal of SMPN I Bukitbatu Bengkalis Riau in improving the competence of PAI teachers is determined by two indicators: (1) Principal of SMPN I Bukitbatu Bengkalis Riau often proposes to the Ministry of Religious Affairs Bengkalis to send delegation teacher of PAI in upgrading or training. (2) Principal of SMPN I Bukitbatu Bengkalis Riau often motivates PAI teachers to improve the competence of teaching based on social piety.

In the first indicator, the Principal of SMPN I Bukitbatu Bengkalis Riau often proposes to the Ministry of Religious Affairs Bengkalis district to send delegations of PAI teachers to SMPN I Bukitbatu Bengkalis Riau in the upgrading and training of teacher certification PAI organized by the Ministry of Religious Affairs of Riau Province or the executive Faculty of Tarbiyah and Teacher-Training UIN Suska Riau. Their impressed quite high. This is the evidence of consistently sending delegation of PAI teachers to follow upgrading and training conducted by the Ministry of Religious Affairs of Riau Province or Faculty of Tarbiyah and Teacher-Training UIN Suska Riau as the institution authorized to organize education personnel education (LPTK) section 213.

The result from the interview with the Principal of SMPN I Bukitbatu Bengklis Riau showed that the school has no problem, as long as there is a willingness and opportunity for PAI teachers to follow any upgrading or training. Indeed, wherever the teachers send, propose, try to seek, sign the file immediately, and get permission, the principal always gives his/her permission. Because the main purpose of these activities is to improve the competence of PAI teachers in SMPN I Bukitbatu Bengklis Riau. This training has a positive impact for the school development and progress. At least, this can arise and increase PAI teachers individual awareness, improve their skills, and increase their motivation in doing the job.

Then, the second indicator, principal often motivates PAI teachers to improve their teaching competence based on social piety. It must be quite high quality. This is shown and reported in the meeting held by the principal and teachers for discussing students' achievement, development and problems. In addition, the principal often motivates PAI teachers to improve their competence by pursuing their education to the next level. Thus, their experience and perspective are getting wider and increasing accordly to the demands, development, and progress as well as demand in this era.

The following data interview with the principal on indicators for motivating and increasing teaching competence of teachers of PAI-based social piety showed that the current emphasis has been packed. The principal often asks teachers, especially the teachers of the PAI, not only to come to teach and go back home when the effective hours of teaching (Lareau, 1987). The teachers must also further enhance their ability and skills to develop the existing curriculum and learning process in a classroom based on social or community piety. They must be able to communicate intensely, effectively, and empathically with students, parents, fellow teachers in the school, and more importantly the community. Furthermore, teacher must have a skill to take advantage for communication and getting information through technology to support 
relation with each other. Indeed, this can be lead for self-development without forgetting, emphasizing, and continuing education to a higher level.

\section{Principal Engagement or Participation in Procurement of Books and Learning Tools of PAI}

Principal involvement and participation in the procurement of books and learning tools of PAI are determined by two indicators. The indicators are 1) the principal discusses the problems of books and learning tools of PAI; and 2) the principal tries to find solutions for teaching media problem which is PAI book that happened to come late.

Both indicators are important. Indeed, this relates to the changing curriculum of PAI that effects the books' procurement and learning tools of PAI in accordance with the new curriculum. The participation of Principal of SMPN I Bukitbatu Bengkalis Riau in solving the problem of book availability and learning tools of PAI is high. It is proven from the letter of request submission about books and learning tools PAI to the Department of Education and Ministry of Religious Bengkalis Regency.

In addition, the steps has been taken by the Principal of SMPN I Bukitbatu Bengklis Riau. $\mathrm{He} /$ she provides guidance to students' parents about the need of PAI learning books for students. This is because PAI textbook is essential for improving the quality of PAI in SMPN I Bukitbatu Bengkalis Riau.

The second indicator relates to the books and learning tools of PAI. This is the involvement or participation of the Principal of SMPN I Bukitbatu Bengkalis Riau for find the solution for book's late arrival and learning tool of PAI. In this indicator, Principal of SMPN I Bukitbatu Bengkalis Riau is also played important role as he/she participated in solving the problem, following an interview with the principal on this matter:

The principal and teachers often hold meetings, discuss on the teachers' preparation, especially the teachers of the PAI and with the School Committee on the problem of delayed arrival of books and learning tools of the PAI. This happens almost every year and almost every year, school will make a request to speed the arrival of books and learning tools PAI to the Department of Education and Ministry of Religious Affairs Bengkalis Regency. Based on the above two indicators of involvement or participation of Principal of SMPN I Bukitbatu Bengkalis Riau in terms of procurement of books and learning tools PAI, it can be categorized high (Lee \& Taylor, 2014; Reynolds Arthur J., Ou Suh- Ruu, \& Topitzes James W., 2004).

\section{Principal Involvement or Participation in Provision of School Facilities and Infrastructures Relating to PAI}

The involvement or participation of Principal in the procurement of school facilities and infrastructure matters related to PAI is determined by two major indicators. The indicators include: (1) Principal of SMPN I Bukitbatu Bengklis Riau discussed the problem of lack of school facilities and infrastructure with regard to PAI; (2) Principal of SMPN I Bukitbatu Bengklis Riau trying to find the solution to the problem of lacking facilities and school infrastructure related to PAI.

The involvement or participation of Principal of SMPN I Bukitbatu Bengkalis Riau in discussing the problem of school facilities and infrastructure that are lacking is high. It is believed that establishing professional learning communities develops capacity and improves students' learning at school (Balyer, Karatas, \& Alci, 2015). This is shown by the ability of Principal of SMPN I Bukitbatu Bengkalis Riau for patching and solving the lack of facilities and infrastructure associated with PAI both to the School Committee and to the Department of Education and Ministry of Religious Affairs of Bengkalis Regency. Despite the fact that the principal has conveyed this matter repeatedly, still, it cannot be solved just yet. This is because of limited ability and skill of School Committee in improving the facilities and school 
infrastructure related to PAI. Also, the matter is beyond the School Committee of SMPN I Bukitbatu Bengklis Riau. It needs help from the higher to overcome is the struggle which is the Department of Education and Ministry of Religious Affairs Bengkalis Riau.

In the second indicator, Principal of SMPN I Bukitbatu Bengklis Riau provides solutions for problems. The solution offered by the principal is high. This is basically associated with the first indicator by filing a request for additional facilities and infrastructure for SMPN I Bukitbatu Bengkalis Riau to the Education Office and the Ministry of Religious Affairs of Bengkalis Regency, in which this is one step ahead to solve the matter .

Based on above two indicators, in fact the Principal of SMPN I Bukitbatu Bengklis Riau, the principal has involved or has a large participation in the procurement of school facilities and infrastructure associated with PAI. Although the results are still suboptimal, the strategy is quite good for improving the quality of the school and education system. This is in a good agreement with other researches (Bandur, 2012; Mo et. al.., 2014).

\section{Principal Involvement or Participation in Improving School Management in the Field of Religion.}

Involvement or participation of principal of SMPN I Bukitbatu Bengklis Riau in improving the quality of school management in the field of religion consists of two participations. The main parameters are: (1) Principal of SMPN I Bukitbatu Bengklis Riau continues to coordinate the implementation of management quality field of religion in schools; (2) Principal of SMPN I Bukitbatu Bengklis Riau facilitates for the implementation of quality management of religious fields in schools.

The first indicator is the involvement or participation of Principal of SMPN I Bukitbatu Bengkalis Riau in coordinating the implementation of religious management quality in schools. This indicator is high. It can be seen from the implementation of the involvement or participation of principal in coordinating for improved performance or value of PAI students, enhancing the competence of PAI teachers, procurement of books and learning tools of PAI, as well as the involvement or other participation. It is clear that the involvement or participation of Principal of SMPN I Bukitbatu Bengkalis, Riau is very dominant and tends to lack of delegation in the task of improving the quality of school management in the field of religion.

Regarding the second indicator, the indicator of involvement or participation of the Principal of SMPN I Bukitbatu Bengkalis Riau in terms of facilitating for the implementation of the quality of religious field management in schools is also quite high. Such involvement or participation is demonstrated by the initiative of the Principal of SMPN I Bukitbatu Bengkalis Riau in the new formation of School Committee as a replacement for the old School Committee, which has expired its stewardship.

Principal of SMPN I Bukitbatu Bengkalis Riau summoned the old School Committee and explained the role mechanism and work program of the new School Committee, in order to allow the insertion of the old committee into the newly formed board. Furthermore, the Principal of SMPN I Bukitbatu Bengkalis Riau explains in detail how the role mechanism and work program of new-School committees should be community-based, as well as possible to organize and strive to strength the religious or activities related to PAI.

Based on the two indicators of involvement or participation of principal which has been stated above that the participation or involvement in improving the quality of religious field management in SMPN I Bukitbatu Bengkalis Riau can be categorized high enough or more than optimal (Liu et. al., 2014).

\section{CONCLUSION}

One of the most fundamental and crucial issues in the field of education is the low quality of education at every level and unit of education, especially primary and secondary education, 
specifically in PAI in public schools. Efforts made to improve the quality of PAI, among others through community-based education programs. The community and all local education stakeholders are given the opportunity to participate and support the implementation process and the organization of education. This study shows that the main problem faced by SMPN I Bukitbatu Bengkalis Riau lies in the main output of PAI is the low of religious practice of students, attitudes, behaviors, morals as well as the association of students who tend to embrace the modern life/contemporary. While the study on the main inputs of PAI also shows that the competence of teachers of PAI who are less able to develop the existing curriculum and not significantly oriented to the pattern of teaching based on social piety, learning facilities and infrastructure of PAI availability, but still not adequate. This study also shows that the Principal's concern on religious issues and the improvement of the quality of PAI learning is relatively high, especially from his programs in conducting Islamic religious studies in national and major days, Duba learning program, tahfidz one day one verse program, holding daily books of yaumi and verses, tajwid or tabsin learning programs for teachers, sacrificial animal repayment programs and highly motivating teachers to have skills and developing an existing curriculum, as well as improving the competence of teaching based on social piety.

\section{BIBLIOGRAPHY}

Aksit, N. (2007). Educational reform in Turkey. International Journal of Educational Development, 27(2), 129-137. https://doi.org/10.1016/j.ijedudev.2006.07.011

Balyer, A., Karatas, H., \& Alci, B. (2015). School principals' roles in establishing collaborative professional learning communities at schools. 7th World Conference on Educational Sciences, 197, 1340-1347. https://doi.org/10.1016/j.sbspro.2015.07.387

Bandur, A. (2012). School-based management developments and partnership: Evidence from Indonesia. International Journal of Educational Development, 32(2), 316-328. https://doi.org/10.1016/j.ijedudev.2011.05.007

Bell, M. P., Connerley, M. L., \& Cocchiara, F. K. (2009). The case for mandatory diversity education. Academy of Management Learning \& Education, 8(4), 597-609. https://doi.org/10.5465/amle.8.4.zqr597

Brinthaupt, T. M., \& Lipka, R. P. (2012). Understanding early adolescent self and identity: Applications and interventions. State University of New York Press. Retrieved from https://books.google.co.id/books?id=6DSHyF7tKkMC

Casson, A., \& Obidzinski, K. (2002). From new order to regional autonomy: Shifting dynamics of "Illegal" logging in Kalimantan, Indonesia. World Development, 30(12), 2133-2151. https://doi.org/10.1016/S0305-750X(02)00125-0

Cheung, R. M. B. (2000). Securing a better future: A Hong Kong school principal's perception of leadership in times of change.

Creswell, J. W. (2012). Educational research: planning, conducting, and evaluating quantitative and qualitative research (4th ed). Boston: Pearson.

Crow, G. M., \& Peterson, K. D. (2010). Principals role in restructuring schools. in P. Peterson, E. Baker, \& B. McGaw (Ed.), International Encyclopedia of Education (Third Edition) (hlm. 6671). Oxford: Elsevier. https://doi.org/10.1016/B978-0-08-044894-7.00423-1

Dimmock, C., \& Walker, A. (2000). Future school administrators: Western and Asian perspectives. Hong Kong: The Chinese University of Hong Kong.

E Johnson-Agbakwu, C., Helm, T., Killawi, A., \& I Padela, A. (2013). Perceptions of obstetrical interventions and female genital cutting: Insights of men in a Somali refugee community (Vol. 19). https://doi.org/10.1080/13557858.2013.828829 
Faguet, J.-P. (2004). Does decentralization increase government responsiveness to local needs?: Evidence from Bolivia. Journal of Public Economics, 88(3), 867-893. https:/ / doi.org/10.1016/S0047-2727(02)00185-8

Fielding, M. (2009). On the necessity of radical state education: Democracy and the common school (Vol. 41). https://doi.org/10.1002/9781444307313.ch3

Fullan, M., \& Watson, N. (2000). School-based management: Reconceptualizing to improve learning outcomes. School Effectiveness and School Improvement, 11(4), 453-473. https://doi.org/10.1076/sesi.11.4.453.3561

Galindo, C., \& Sheldon, S. B. (2012). School and home connections and children's kindergarten achievement gains: The mediating role of family involvement. Early Childhood Research Quarterly, 27(1), 90-103. https://doi.org/10.1016/j.ecresq.2011.05.004

Ahmad, R. H. (1998). Educational development and reformation in Malaysia: past, present and future. Journal of Educational Administration, 36(5), 462-475. https:// doi.org/10.1108/09578239810238456

Khong, L. Y.-L., \& Ng, P. T. (2005). School-parent partnerships in Singapore. Educational Research for Policy and Practice, 4(1), 1-11. https://doi.org/10.1007/s10671-005-5617-6

Kim, J. H. (2013). When East Asia meets Europe (Doctoral Dissertation). Freie Universitat, Berlin.

Lareau, A. (1987). Social class differences in family-school relationships: The importance of cultural capital. Sociology of Education, 60(2), 73-85. https://doi.org/10.2307/2112583

Lee, J., \& Taylor, M. S. (2014). Dual roles in psychological contracts: When managers take both agent and principal roles. Human Resource Management Review, 24(1), 95-107. https://doi.org/10.1016/j.hrmr.2013.03.001

Lewis, C. C., \& Tsuchida, I. (1999). A lesson is like a swiftly flowing river: How research Lessons improve Japanese education. Improving Schools, 2(1), 48-56. https://doi.org/10.1177/136548029900200117

Liu, J., Qu, H., Huang, D., Chen, G., Yue, X., Zhao, X., \& Liang, Z. (2014). The role of social capital in encouraging residents' pro-environmental behaviors in community-based ecotourism (Vol. 41). https:// doi.org/10.1016/j.tourman.2013.08.016

Mazrui, A. A. (1992). Towards diagnosing and treating cultural dependency: The case of the African university. International Journal of Educational Development, 12(2), 95-111. https:// doi.org/10.1016/0738-0593(92)90032-H

Mo, D., Luo, R., Liu, C., Zhang, H., Zhang, L., Medina, A., \& Rozelle, S. (2014). Text messaging and its impacts on the health and education of the poor: Evidence from a field experiment in rural China (Vol. 64). https://doi.org/10.1016/j.worlddev.2014.07.015

Noh, M. A. C., Ludin, M. S. M., \& Suhid, A. (2013). Teaching competency among Islamic educators in Malaysia, 3.

Ornstein, A. C. (1991). Teacher effectiveness research: Theoretical consideration. Barkeley: McCutchan Publishing Corp.

Rafee, A. B. (2014). Exploring islamic education teachers' competency in teaching tilawah Al-Quran in two selected secondary schools in gombak: a case study (Dissertation). International Islamic University, Malaya, Malaya.

Reynolds Arthur J., Ou Suh- Ruu, \& Topitzes James W. (2004). Paths of effects of early childhood intervention on educational attainment and delinquency: A confirmatory analysis of the Chicago child- parent centers. Child Development, 75(5), 1299-1328. https:// doi.org/10.1111/j.1467-8624.2004.00742.x

Rondinelli, D. A. (1981). Government decentralization in comparative perspective: Theory and practice in developing countries. International Review of Administrative Sciences, 47(2), 133-145. https://doi.org/10.1177/002085238004700205 
Stromquist, N. (2007). Internationalization as a response to globalization: Radical shifts in University environments (Vol. 53). https://doi.org/10.1007/s10734-005-1975-5

Whittington, R. (1996). Strategy as practice. Long Range Planning, 29(5), 731-735. https://doi.org/10.1016/0024-6301(96)00068-4 